STUDIA UKRAINICA POSNANIENSIA, vol. VI: 2018, pp. 37-43.

ISSN 2300-4754.

DOI: $10.14746 /$ sup.2018.6.04

\title{
ДІАРІУШ ЯК ЖАНР ЩОДЕННИКОВОГО ДИСКУРСУ
}

\author{
СВІТЛАНА ІГНАТЬЕВА \\ Національний гірничий університет, Дніпро — Україна \\ sv.ihnatieva@gmail.com \\ DIARIUSZ JAKO GATUNEK DYSKURSU PAMIĘTNIKARSKIEGO \\ SWITŁANA IHNATIEWA \\ Narodowy Uniwersytet Górniczy, Dnipro — Ukraina
}

STRESZCZENIE. W artykule przedstawiono cechy charakterystyczne diariusza jako gatunku dyskursu pamiętnikarskiego. Za pomocą analizy opozycyjnej ustalono cechy dyferencyjne dziennika, scharakteryzowano cechy wspólne, łączące go z niektórymi gatunkami publicystyki, określono możliwości odzwierciedlenia ewolucji osoby autora poprzez gatunek pamiętnikarski.

\section{DIARIUSH AS A GENRE OF DIARY DISCOURSE \\ SVITLANA IHNATIEVA \\ National Mining University, Dnipro — Ukraine}

ABSTRACT. The article deals with the essence of "diariush" as a literary genre of a diary discourse. The method of an oppositional analysis has been used in the study to identify the distinguishing characteristics of the diary. It also describes the characteristics which the diary has in common with other genres of publicistic writing. In the article it has been stated that the diary genre has the ability to reflect the author's personality evolution.

Щоденник - ие своєрідний інтелектуальний і душевний стриптиз, що потребує від автора неабиякої сміливості й відвертості.

(Ірена Карпа)

$\mathrm{Y}$

сучасній лінгвістиці пожвавлюється зацікавленість дослідження діаріушем як жанром щоденникового дискурсу. Значний інтерес до вивчення щоденника зумовлений як власне лінгвістичними чинниками, так і змінами в суспільстві: новими загостреннями суспільних проблем у світі, соціальними пошуками, процесами духовного відродження, поверненням до глибокого осмислення історичного минулого, утіленого в літературному щоденнику як інтимно-сповідувальному жанрі, духовному заповітові нащадкам.

Однак зауважимо, що привабливість щоденника як жанру полягає саме в тому, що він репрезентує авторське бачення, розкриває його світогляд й наскрізно пройнятий авторськими почуттями й емоціями. Малодослідженою ланкою залишається письменницький літературний щоденник. Необхідно конкретизувати жанрову специфіку письменницького щоденника як форми, класифікувати його провідні ознаки, а також розглянути його в рамках окремих літературно-художніх напрямів, зокрема модернізму.

Цей жанр цікавий для аналізу з погляду історичної науки, літературознавства, психолінгвістики, теорії комунікації й теорії мовленнєвих жанрів, прагматики та інших наукових напрямів, однак варто розглянути цей феномен комплексно. 
Щоденник XX століття не тільки включає сучасність у широкий культурний контекст, а й наповнює його зміст розповідями про суперечність і драматичність епохи. Щоденник - це історія через призму бачення його автора, його впорядкований досвід, формування його як особистості. Саме щоденник віддзеркалює віхи життєвого шляху автора, оголює таємниці його душі, іноді навіть найінтимніші, стає певною мірою сповіддю перед читачем.

Дискусійність базового поняття лінгвогенристики спричинена багатоаспектністю тих жанрових класифікацій, що існують у різних сферах мовлення.

Зінтегровуємо дослідницький інтерес навколо діаріуша як письменницького літературного жанру щоденникового дискурсу. Основний здобуток виконаного дослідження - з'ясована дискурсна сутність літературного щоденника як жанру, що посприяло не тільки визначенню його основних жанротворчих ознак, здійсненню текстового аналізу щоденника, а й, що важливо, окресленню можливостей відображати еволюцію особистості автора в діарійному жанрі.

Попри значну кількість наукових праць, присвячених теорії мовленнєвих жанрів, визначення й виокремлення їхніх особливостей, співвідношення між первинними і вторинними жанрами тощо, до сьогодні залишається питанням відкритим. Щоденникові повідомлення не лише віддзеркалюють час і місце їхнього написання, тип культури, який вони репрезентують, а й відкривають шлях у “творчу лабораторію” діариста, уможливлюють простеження динаміки авторського задуму.

Зауважимо, що в сучасній лінгвістиці простежується постійний інтерес до проблеми жанру, однак категорія мовленнєвий жанр (далі МЖ) дотепер у стадії формування й універсалізації.Сьогодні жанроцентризм претендує на лідерство, а вчення про жанри мовлення виформовується в новий перспективний напрям - неолінгвістичний, який учені називають жанроцентричним, жанрологічним, генологічним, генристичним.

Увагу сучасних дослідників привертають питання вивчення мовленнєвих жанрів у різних напрямах лінгвістики, зокрема теорії мовленнєвих актів (Н. Арутюнова 1992, Ф. Бацевич 2005, А. Вежбицька 1997, О. Іссерс 2006, С. Гайда 1986, Л. Капанадзе 2005, Л. Компанцева 2005, А. Селютін 2009, Т. Шмелева 1995, А. Зализняк 2010, А. Searle 2000, Р. Boerner 1969, J. Jurgensen 1979, R. Görner 1986, R. Blythe 1989, G. Hocke1991, T. Mallon 2005, C. Bogaert, P. Lejeune 2006, A. Gräser 1955), соціально-психологічному напрямі (К. Сєдов), з позицій когнітології (А. Баранов), герменевтики (Г. Богін). У цьому дослідженні спираємося на теоретичні засади лінгвістичної генології, теорії мовленнєвих актів і прагмалінгвістики (М. Бахтін, Ф. Бацевич, А. Вежбицька та ін.).

До сьогодні питання про жанрову належність щоденника є дискусійним. Особлива увага зосереджена навколо правомірності віднесеності щоденника до самостійного жанру.

Традиційно С. Рудзієвська розглядає щоденник як жанр, що посідає проміжне місце між жанрами художньої і документальної літератури․․ Цікавою $з$ цього погляду є праця Л. Гінсбург $O$ психологической прозе 2 . Зазначена дослідниця визначає щоденник як жанр “проміжної прози” й відносить до неї ще й мемуарно-документальні джерела. Такої ж думки дотриму-

\footnotetext{
${ }^{1}$ С. В. Рудзи ев ская, Художественные возможности и истоки жанра дневника писателя, [в:] „Вестник Литературного института им. А. М. Горького”, Москва 2002, № 1, с. 85-92.

${ }^{2}$ Л.Я.Гин з бу рг, О психологической прозе, Москва 1999.
} 
ються А. Тартаковський ${ }^{3}$, В. Оскоцький ${ }^{4}$, Д. Затонський ${ }^{5}$ О. Галич 6 . Інші вчені - Л. Гапека й А. Лашкевич - визначають щоденник як явище сублітератури․․ О. Єгоров уважає щоденник психологічною літературою ${ }^{8}$. Якщо розглядати щоденник 3 художньо-композиційної позиції, то, на думку Т. Скиргайло ${ }^{9}$, це „літературно-побутовий жанр, у якому оповідь ведеться від першої особи у формі щоденних або періодичних записів про події поточного життя (особистого, громадського, літературного)" $"$.

У межах цього дослідження розрізняємо типи щоденникових текстів: нелітературний та літературний. Так, М. Міхеєв ${ }^{11}$ уводить в обіг поняття "наївний” щоденник, тобто такий, що написаний зазвичай непрофесіональним, "наївним”, пересічним і літературно недосвідченим автором. Щоденники нелітературного типу оприлюднюють приватне життя автора, вони не претендують на унікальність. Літературний щоденник становить повноцінний художній твір, його зміст відображає й власне життя автора на тлі суспільних та історичних подій. 3 одного боку, літературний щоденник становить художній витвір без автобіографічних ознак, з іншого - якнайповніше відображає реальні автобіографічні події життя автора. Показовою щодо літературного щоденника є думка Катрін Вьолле та Олени Гречаної ${ }^{12} .3$ одного боку, вони відносять цей тип щоденника до інтимної й документальної прози, з іншого - указують на художній вимисел, певну імпровізацію, що дає змогу віднести літературний щоденник до проміжної позиції між документальною і художньою літературою, вимислом і фактом. Ф. Лежен ${ }^{13}$ сформулював “теорію автобіографічного пакту”, що сприяє визначенню підтипу літературного щоденника, а також указує на ступінь його автобіографічності. Він виокремлює чотири критерії, що, на його думку, властиві кожному автобіографічному жанрові (й щоденнику також):

- ідентичність імен автора й героя (оповідача), тобто автор тексту і наратор повинні збігатися;

• достовірність викладених подій, зумовлена відповідальністю, яку несе автор за правдивість повідомлень;

• опис власного життя, життєвих історій;

- ретроспективність викладу.

${ }^{3}$ А. Г. Тартаковски й, Русская мемуаристика XVIII-первой половины XIX в.: От рукописи к книге, Москва 1991, с. 8.

${ }^{4}$ В. Д. Оскоцки й, Дневник как правда, [в:] „Вопросы литературы”, Москва 1993, № 5, с. 3-58.

5 Д. В. З атон с к ий, Сцепление жанров (место автобиографии, мемуаров, дневника в становлении и жизни современного романа), [в:] Жанровое своеобразие прозы Запада, Киев 1989, с. 4-58.

${ }^{6}$ O . А. Г Гал и ч, Олесь Гончар у вимірах Non fiction, Луганськ 2011.

7 Л. М. Гапека, А. В. Лашке в ич, Личный дневник как жанр сублитературы: проблема структуры и функиии "diary” в контексте межкультурной коммуникации, [в:] Синтез документального и художественного в литературе и искусстве, сб. статей и матер. Межд. науч. конф. (3-6 мая 2006 г.), Казань 2007, с. 391-396.

${ }^{8}$ О.Г.. Егор ов, Русский литературный дневник ХІХ века. История и теория жанра: Исследование, Москва 2003.

${ }^{9}$ T. О. С к р иг ай ло, Методика обучения работе над сочинениями нетрадиционных жанров, Москва 2006, с. 149.

${ }^{10}$ Там же

${ }^{11}$ М. Ю. Михее в, Фактографическая проза или пред-текст. Дневники, записные книжки, “обыденная” литература. Текст, [в:] „Человек”, Москва 2004, № 2, с. 137-142.

${ }^{12}$ Е. П. Гречаная, Автобиографические тексты российских женщин ХVIII в. на франиузском языке, [в:] Автобиографическая практика в России и во Франщии, сб. статей, под ред. К. Вьолле и Е. Гречаной, Москва 2006, с. 30-56.

${ }^{13}$ Ф. Лежен, „Когда кончается литература?”, беседа с Ел. Гальцевой от 28 окт. 2000 г., [в:] Автобиографическая практика в России и во Франции..., с. 261-275. 
Ф. Лежен, що важливо, указує на різний ступінь присутності цих ознак у щоденниковому тексті.

Щоденник - це насамперед текст, що складається з окремих датованих повідомлень, які поповнюються 3 певною періодичністю. Чітка хронологічна послідовність записів з фіксацією подій, явищ з життя автора, їхнє обов'язкове датування - синхронне, у момент їхнього створення становить ту особливість, яка співвідносить щоденник з поточною мовленнєвою діяльністю і визначає його пограниччя між текстом і дискурсом.

Диференційні ознаки щоденника виокремимо методом опозиційного аналізу:

1) біографія і щоденник: суб'єкт і об'єкт оповіді збігаються чи не збігаються. У щоденнику комунікант-продуцент, яким $є$ реально існуюча людина (автор), одночасно є як суб'єктом, так і об'єктом; у біографії - суб'єкт оповіді та її об'єкт не збігаються, а автором (комунікантом-продуцентом) може бути кожний суб'єкт, той, хто досліджує життя об'єкта;

2) автобіографія і щооенник: ретроспективному відображенню подій після певного проміжку часу протиставляється синхронність подій, що відбулися в житті автора, зафіксовані в щоденниковому тексті у формі поденних записівповідомлень;

3) літературний портрет і щцоденник: літературний портрет, з одного боку, відтворює цілісність фізичного, духовного, творчого обличчя об'єкта, усебічно розкриває лейтмотив, пафос його життя, з іншого - обмежується певним часовим проміжком; щоденник же композиційно дискретний, у ньому багатоаспектно й динамічно відображене життя об'єкта, простежується процес становлення особистості автора;

4) нарис і щцоденник: у нарисі опис реальних подій і фактів супроводжується авторським домислом, а в щоденнику відсутні навіть окремі елементи домислу;

5) лист і щцоденник: звертання, адресність епістолярію $€$ його конституційною особливістю, у щоденнику адресант й адресат повідомлення збігаються, щоденник - розмова автора із собою, автокомунікація (Ю. Лотманом, Т. Космеда);

6) хроніка і щцоденник: у хроніці час є основним суб'єктом історичного процесу, організуючою домінантою сюжету, в щоденнику — чільне місце належить особистості автора;

7) записна книжска $\boldsymbol{i}$ щцоенник: записна книжка фіксує окремі творчі нотатки - авторські задуми, початкові ескізи, щойно почуті окремі слова, вислови, слугує для автора насамперед практичним посібником, що дає змогу наочно поділитися враженнями від побаченого / почутого, миттєво зафіксувати творчі думки, що, наповнюючись змістом, набувають форми, перетворюються в художні деталі. Щоденник дає змогу не тільки проникнути у творчу лабораторію його автора (письменника), а й простежити динаміку його особистого життя, розвиток духовного світу; щоденник містить ретельно занотований авторомписьменником матеріал для майбутніх літературних творів, психологічні характеристики сучасників, а ще роздуми, розмисли, оцінки творчого й суспільного життя. Тому щоденник виконує не тільки мнемонічну, а й естетичну, автометадескриптивну функції.

Складно, а то й неможливо порівняти щоденник з іншими жанрами щодо глибини й широти відтворення в них духовної сфери часу. Автори щоденників, 
позначаючи окремі віхи свого життєвого шляху, разом з тим проливають світло на мотиви вчинків інших людей, указують на причинно-наслідкові зв'язки суспільних явищ, прогнозують й оцінюють суспільні події. Авторська позиція набуває певної соціальної значимості, щоденник уже не сприймається як літопис чи хроніка приватного життя автора. Тяжіння до публіцистичності сприяє усвідомленню історичної значимості щоденникової форми, переконаності в тому, що в майбутньому окремий щоденник слугуватиме важливим підгрунтям для характеристики епохи, що особливо важливе в епоху соціальних та геополітичних змін.

Щоденник дає змогу по-особливому відчути епоху, зокрема визначає погляди - філософські, політичні, моральні, - що переважають у духовному житті людей цього періоду; загальний настрій мас, відношення суспільства до офіційної ідеології, перевагу суспільної активності або пасивності та ін.; дають багатий матеріал для визначення політичних лідерів часу, репрезентують програму взаємин між письменником і владою, суспільством і літературою.

Зіставлення щоденника з публіцистичними жанрами дає змогу схарактеризувати спільні для них ознаки, що дають можливість віднести літературний щоденник до жанрів публіцистики. До них належить:

a) суб' єктивність - внутрішня свобода щоденника дає змогу вільно оцінювати історичні події, факти, сучасників; сповідуватися перед собою; заглиблюватися у власний внутрішній світ. Наголосимо на тому, що діаріуш $є$ глибоко особистісним твором;

б) синтетичність - щоденник містить такі складники, які властиві усьому жанровому розмаїттю періодичних видань;

в) суб 'єктивність - виявлення авторської оцінки; аналітичність, розмисли, узагальнення - усвідомлення того, що відбувається навколо, властиве як жанру щоденника, так й іншим публіцистичним жанрам;

г) документальність, подієвість - діаріуш фіксує конкретні події, факти, явища в певній хронологічній послідовності, він $є$ важливим історичним джерелом, слугує тим інформативним тлом, що стосується певного періоду суспільного життя;

г) соціальна значущість - відображення соціально значущих подій. Проблеми, що віддзеркалюються в щоденникові, як правило, актуальні для громадськості;

д) оповідна структура, засоби мовленнєвої виразності - емоційна насиченість, неповна структурна оформленість синтаксичних конструкцій; інтертекстуальність.

До жанротворчих ознак щоденника належить: синхронність - автор фіксує події не гаючи часу, негайно, "по свіжих слідах", дискретність - фрагментарність записів, переривчастість; датування - фіксація часу написання повідомлення; регулярність - окремі записи ведуться регулярно.

Щоденник є унікальним засобом систематизації й упорядкування власного досвіду, можливістю зберегти як переживання особистості, так і фактичні дані, пов'язані із цими переживаннями.

Чітка хронологічна послідовність записів 3 фіксацією подій, явищ 3 життя автора та їхнє обов'язкове датування - синхронне, у момент їхнього створення становить ту особливість, що співвідносить щоденник з поточною мовленнєвою діяльністю і визначає його пограниччя між текстом і дискурсом. 
Особливістю щоденника як літературного жанру є сповідувальність спрямованість на внутрішній світ автора, саморефлексія; діалогічність - взаємодія $з$ потенційним читачем; синтетичність - злиття жанрових кордонів.

Фактографічні методи щоденника виражені через хронологічну й онтологічну послідовність. Автор проникає в суть явищ, з'ясовує прихований взаємозв'язок відображуваного предмета.

У щоденниках особистість автора роздвоюється на людину, яка власне пише щоденник, і людину, якій призначені записи.

Специфіка адресності щоденника визначає його основну жанротворчу характеристику - імпліцитність мовлення, „при якій усуваються мовленнєві та смислові складники, зорієнтовані на «справжнього адресата»" 14.

На думку I. Вознесенської, щоденникові тексти визначають можливість опустити очевидні відомості, факти, чому сприяє високий ступінь присутності імпліцитно вираженої інформації ${ }^{15}$.

Щоденникові записи становлять системний тип мовлення, організовані строго у відповідності з визначеним алгоритмом (приуроченість до дати, події).

Системність записів спрощує проведення всебічного лінгвістичного аналізу.

Щоденникові записи - це чітко структуровані й тривалі в часі оповіді, що становлять багатий матеріал для дослідження. Щоденники нерідко охоплюють усе життя автора, що дає змогу читачеві простежити за еволюцією мовної особистості, змінами складників її ідеолекту, реконструювати зміст ії світовідчуття.

Основними прагматичними одиницями щоденникового тексту слугують егоцентричні та експресивні лексичні одиниці, риторичні запитання, питально-відповідні формули, звертання до себе, засоби організації аутодіалогу, що реалізують основну функцію автокомунікації.

Можливо, стереотипна думка про щоденниковий жанр як камерний викликана традиційною інтимністю щоденникового змісту. Проте можливість зберегти непідцензурну інформацію викликає бажання зробити не тільки особисті, інтимні записи, актуальні для однієї людини й тільки в певний момент, але й записи суспільного змісту, нерідко небезпечні для життя, такі, що можуть мати серйозні наслідки. Існування таких щоденників викликає низку питань - чому автори, які мали можливість публікувати свої тексти, ризикували життям, шифрували, не розлучалися ні на годину, носили із собою в бомбосховища, закопували й передавали свої щоденники перед смертю близьким, які зберігали рукописи довгі роки як найбільшу коштовність? Це значить, що інтимність не завжди припускає небажання опублікувати свій здобуток, а скоріше свідчить про неможливість це зробити. Ідеться, очевидно, про сповідувальний характер щоденникового жанру, а не інтимний. Потреба висловитися закономірно мотивує потребу ведення документа, не розрахованого на небажаного читача.

Щоденниковий лист відрізняється настільки сміливими авторськими оцінками, висновками, що очевидно: подібні записи стали в сукупності свідченням епох, у яких завдяки специфіці жанру автори дозволяють собі не соромитися в судженнях.

Діаріуш є безпосереднім віддзеркаленням внутрішнього духовного життя діариста, оскільки для його власного “я" не існує жодних кордонів, що існують для іншої чужої свідомості.

${ }_{14}$ И. М. Вознесенская, Семантическая структура и языковые особенности дневникового текста, [в:] Исповедальные тексты культуры, Матер. межд. науч. конф., под ред. М. С. Ув а ров а , 18-19 ноября 2006 г., СПб. 2007.

${ }^{15}$ Там же, с. 121. 
У щоденнику на передньому плані - особистісне світовідчуття автора, його виняткове бачення та розуміння навколишньої дійсності. Саме архітектоніка щоденника поєднує його композиційну модель з індивідуальним світовідчуттям.

Щоденник, як жодний інший жанр, уможливлює дослідження особистості автора, вивчення трансформації особистості. Як правило, автори щоденників це люди 3 яскраво вираженою індивідуальністю, особистості часто виняткові, їхнє життя може мати інтерес не менш глибокий і повчальний, ніж історія цілого народу, що набуває значення і як психологічний матеріал.

Щоденники пропонують аналіз власної душі, аналіз процесу розвитку самосвідомості. Комунікант-реципієнт може простежити процес інтелектуального й духовного зростання особистості.

Отже, діаріуш виразно репрезентує еволюцію особистості автора, особливо за умови, коли ведеться протягом років, а то й десятиліть і має систему специфічних ознак, що характеризує його належність до особливого типу дискурсу, відповідного мовленнєвого жанру. 